\title{
PENGARUH KUALITAS PELAYANAN DAN NILAI PELANGGAN TERHADAP KEPUASAN PELANGGAN
}

\begin{tabular}{|c|c|}
\hline \multicolumn{2}{|c|}{$\begin{array}{c}\text { Oleh : } \\
\text { Nuni Nurhalimah } \\
\text { Ade Nurhayati KD } \\
\text { Program Studi Manajemen - STIE Dr.Khez. Muttaqien Purwakarta } \\
\text { Email : nurhalimahnuni21.nn@ @mail.com } \\
\text { Email : adenurhayati @ stiemuttaqien.ac.id } \\
\text { DOI Artikel : https://doi.org/10.34308/eqien.v6i2.93 }\end{array}$} \\
\hline Article Info & Abstract \\
\hline $\begin{array}{l}\text { Article History: } \\
\text { Received 16 Agustus } 2019 \\
\text { Accepted } 30 \text { Agustus } 2019 \\
\text { Available Online 05 September } \\
2019\end{array}$ & $\begin{array}{l}\text { Business continuity (going concern) is the main purpose of } \\
\text { a business entity since the establishment of the business } \\
\text { entity is closely related to how management can manage the } \\
\text { business both from financial factors and non-financial } \\
\text { factors. This research was conducted to find out what things } \\
\text { can affect customer satisfaction in a purchase. In this } \\
\text { research used two independent variable of service quality } \\
\text { (X1) and customer value (X2), while customer satisfaction } \\
\text { (Y) as dependent variable. } \\
\text { Based on the results of the analysis, found that both } \\
\text { independent variables have a significant and positive effect } \\
\text { on the dependent variable. Service quality variable has } \\
\text { positive effect } 0,425 \text { with significance level } 0,003 \text {. The } \\
\text { customer value variable has a positive effect of } 0.486 \text { with a } \\
\text { significance level of } 0.000 \text {. Adjusted } R \text { Square of the three } \\
\text { variables is } 23.7 \text { percent, which means that the two } \\
\text { independent variables are able to explain the variation in } \\
\text { the dependent variable of } 23.7 \text { percent with } 76.3 \text { percent } \\
\text { explained by other variables not used in this study. }\end{array}$ \\
\hline $\begin{array}{l}\text { Keyword: } \\
\text { Customers Satisfaction, } \\
\text { Service Quality, Costumer } \\
\text { Value }\end{array}$ & \\
\hline
\end{tabular}

\section{PENDAHULUAN}

Sebagai salah satu entitas bisnis yang sedang berkembang, Saung Manglid harus memperhatikan tujuannya dalam melakukan usaha. Salah satu tujuan suatu entitas bisnis adalah mewujudkan kepuasan pelanggan. Menurut Kotler dan Keller (Hami, Suharyono, \& Hidayat, 2016) kepuasan pelanggan adalah perasaan senang atau kecewa seseorang yang timbul karena membandingkan kinerja nyata yang dipersepsikan terhadap produk, dibandingkan ekpektasi pelanggan sebelum penggunaan produk.
Kepuasan pelanggan merupakan hal penting bagi eksistensi suatu bisnis serta, memuaskan pelanggan juga dapat meningkatkan kualitas bisnis dalam bersaing dengan bisnis-bisnis sejenis.

Kualitas pelayanan menjadi salah satu faktor utama dalam membentuk kepuasan pelanggan, pelanggan akan merasa puas apabila ia mendapatkan pelayanan yang sesuai dengan harapannya, bahkan mungkin lebih dari apa yang diharapkan.

Selain kualitas pelayanan, nilai pelanggan juga menjadi faktor yang membentuk kepusan 
konsumen. Nilai pelanggan merupakan persepsi atau pandangan terhadap sebuah produk/perusahaan. Nilai pelanggan ini dapat digambarkan sebagai penilaian secara menyeluruh manfaat yang diterima konsumen dibandingkan dengan biaya yang sudah dikeluarkan serta pengorbankan yang dirasa untuk mendapatkan manfaat tersebut.

Menurut penelitian terdahulu, nilai pelanggan bisa mempengaruhi kepuasan pelanggan. Sejalan dengan penelitian yang dilakukan Woro Mardikawati (2013) bahwa nilai pelanggan berpengaruh positif dan signifikan terhadap kepuasan pelanggan.

Berdasarkan latar belakang yang telah diuraikan sebelumnya, maka rumusan masalah penelitian ini adalah Bagaimana pengaruh kualitas pelayanan dan nilai pelanggan secara bersama-sama terhadap kepuasan pelanggan di Saung Manglid?

Untuk mengetahui pengaruh kualitas pelayanan dan nilai pelanggan terhadap kepuasan pelanggan secara bersama-sama di Saung Manglid

\section{KAJIAN PUSTAKA DAN PEGEMBANGAN HIPOTESIS Kualitas Pelayanan (Service Quality)}

Menurut Fandy Tjiptono (Januar, 2016:266), dalam memberikan penilaian mengenai kualitas pelayanan yang diberikan perusahaan, konsumen memberikan beberapa kriteria yang secara garis besar adalah :

1. Kehandalan (Reability)

Yaitu kemampuan untuk melaksanakan jasa yang dijanjikan dengan terpercaya dan akurat.

2. Daya tanggap (Responsive)

Yaitu kemampuan untuk membantu pelangaan dan memberikan jasa dengan cepat.

3. Kepastian (Assurance)

Yaitu pengetahuan dan kesopanan karyawan dan kemampuan mereka untuk menimbulkan keyakinan dan kepercayaan.

4. Empaty (Empathy)

Yaitu kesediaan untuk peduli memberikan pelatihan pribadi kepada pelanggan.

5. Berwujud (Tangible)

Yaitu penempatan fasilitas fisik, personil dan materi.

\section{Nilai Pelanggan (Customer Value)}

Menurut

Tjiptono

(2005:296)

mendefenisikan nilai pelanggan adalah ikatan emosional yang terjalin antara pelanggan dan produsen setelah pelanggan menggunakan produk dan jasa dari perusahaan dan mendapati bahwa produk atau jasa tersebut memberi nilai tambah.

Dimensi Nilai Pelanggan menurut Sweeney \& Soutar dalam Tjiptono (2011:376) terdapat 4 aspek utama dari nilai pelanggan yaitu:

1. Emotional Value (Nilai Emosional), merupakan kemampuan yang berkaitan dengan kesan perasaan atau emosional yang diakibatkan oleh penggunaan produk.

2. Social Value (Nilai Sosial) merupakan kemampuan yang suatu produk yang berkaitan dengan kemampuannya dalam meningkatkan kesan sosial yang baik dalam masyarakat.

3. Perfomance Value (Nilai Kualitas) kemampuan suatu produk yang dinilai memiliki kinerja dan fungsi yang bagus.

4. Price Value (Nilai Harga) merupakan kemampuan suatu produk yang diperoleh dari harga yang terkesan memiliki efisensi harga.

\section{Kepuasan Pelanggan (Customer Satisfaction)}

Menurut Tjiptono (Hami, Suharyono, \& Hidayat, 2016) kepuasan pelanggan merupakan suatu tingkatan dimana keinginan dan harapan pelanggan bisa tercapai sehingga pembeli merasakan apa yang diperoleh sesuatu yang sama dengan apa yang diharapkan.

Hawkins dan Lonney dikutip dalam Tjiptono (2001:101) atribut pembentuk kepuasan terdiri dari:

1. Kesesuaian harapan

2. Minat berkunjung kembali

3. Kesediaan merekomendasikan

\section{Hipotesis}

Diduga kualitas pelayanan dan nilai pelanggan berpengaruh terhadap kepuasan pelanggan di Saung Manglid Kiarapedes-Purwakarta

\section{METODE PENELITIAN}

Dalam penelitian ini yang menjadi objek adalah variabel bebas (independent variable) yang terdiri dari kualitas pelayanan dan nilai pelanggan. Kemudian variabel terikat (dependen variabel) adalah kepuasan pelanggan.

Populasi dalam penelitian ini yakni konsumen yang melakukan pembelian di Saung Manglid pada bulan September sampai dengan bulan November 2017 sebanyak 1.602 orang. 
Teknik sampling yang digunakan dalam penelitian ini adalah non probability sampling, dengan metode sampel insidental. Berdasarkan rumus Slovin, Responden yang diteliti sebanyak 95 responden.

Lokasi yang menjadi tempat penelitian dalam pembuatan proposal skripsi ini adalah Saung Manglid Kiarapedes Wanayasa Purwakarta.

\section{HASIL DAN PEMBAHASAN}

Hasil indeks jawaban responden dimana kualitas pelayanan menyatakan bahwa rata-rata responden menyatakan tidak setuju terhadap kepuasan pelanggan yaitu dengan skor 2,2 kategori tersebut termasuk skor nilai buruk. Dari data tersebut kita lihat tanggapan responden terhadap karyawan melakukan pelayanan kepada pengunjung yang datang, pelayanan yang diberikan karyawan sesuai dengan standar pelayanan di Saung Manglid, karyawan melakukan pelayanan sesuai dengan kedatangan pengunjung, karyawan sigap melayani keluhan pengunjung, karyawan sigap melayani kebutuhan setiap pengunjung yang datang, karyawan sigap merespon keluhan pengunjung, karyawan sesegera mungkin mengantarkan makanan yang dipesan pengunjung sesuai urutan pemesanan, karyawan santun dalam melayani pengunjung, restoran mampu membuat pengunjung percaya akan pelayanan yang diberikan, pengunjung merasa aman ketika berada di Saung Manglid, karyawan mengetahui informasi mengenai keadaan restoran, pelayanan yang diberikan pihak restoran sebadning kepada setiap pengunjung yang datang, karyawan memperhatikan keinginan setiap pengunjung, karyawan memahami kebutuhan pengunjung, karyawan memenuhi keinginan setiap pengunjung, tersedia fasilitas yang memadai, kelengkapan fasilitas yang disediakan pihak restoran memberikan kenyamanan bagi pengunjung, perlengkapan yang digunakan untuk makan pengunjung tersedia lengkap di restoran, tampilan furniture (desain) ruangan restoran membuat nyaman pengunjung, karyawan memberikan informasi yang jelas padas etiap pengunjung yang datang.

Nilai pelanggan menunjukan bahwa ratarata menyatakan dengan skor akhir 2,6 dengan kriteria buruk. Dibuktikan dengan respon konsumen terhadap ada keinginan dari pelanggan untuk datang ke saung manglid, pelanggan merasa senang setelah berkunjung ke saung manglid, saung manglid merupakan tempat kuliner yang prestisius (bergengsi) untuk dikunjungi, pelanggan terkesan dengan keadaan di saung manglid, berkunjung ke saung manglid memberikan manfaat bagi pengunjung, pelayanan yang diberikan pihak saung manglid kepada pengunjung konsisten, biaya yang dikeluarkan pelanggan sesuai dengan dengan apa yang didapatkan, biaya yang dikeluarkan untuk produk saung manglid relatif lebih baik daripada produk lain. Kebanyakan item pernyataan dinyatakan dengan tidak setuju, maka jelas secara keseluruhan mempengaruhi Kepuasan Pelanggan.

Kepuasan Pelanggan menunjukan ratarata responden menyatakan ragu terhadap pembelian tak terencana dengan skor akhir 2,42 dengan kriteria buruk. Dari data tersebut terlihat makanan yang disajikan sesuai dengan harapan pengunjung, pelayanan oleh karyawan sesuai dengan yang diharapkan pengunjung, fasilitas penunjang yang didapat sesuai dengan harapan pengunjung, pengunjung tertarik untuk melakukan kunjungan berikutnya, pengunjung tertarik untuk melakukan kunjungan kembali dengan manfaat produk, pengunjung datang kembali ke saung manglid dengan fasilitas yang memadai, pengunjung bersedia menyarankan temannya untuk berkunjung ke saung manglid, pengunjung bersedia meyarankan temannya untuk membeli produk yang ditawarkan saung manglid, dengan nilai manfaat yang diperoleh di saung manglid pengunjung tertarik untuk menyarankan kepada temannya.

\section{Estimasi Model Penelitian}

1. Koefisien korelasi antar variable independent dan dependen yaitu diketahui antara kualitas pelayanan $\left(\mathrm{X}_{1}\right)$ dengan kepuasan pelanggan (Y) nilai signifikasi $0,003<0.05$ yang berarti terdapat korelasi yang signifikan. Dimana nilai pearson correlation sebesar 0,425 yang bernilai positif menunjukan bahwa 1 terhadap Y memiliki hubungan searah. Koefisien korelasi antara variabel nilai pelanggan (X2) dengan kepuasan pelanggan (Y) memiliki nilai signifikasi $0,000<0.05$ yang berarti terdapat korelasi yang signifikan dengan nilai pearson korelasi sebesar 0,486 yang bernilai positif tergolong rendah.

2. Dari hasil analisis diatas dapat dilihat bahwa model regresi linear berganda adalah $Y=15,072+0,128 X_{1}+\mathbf{0}, 455 X_{2}$ 
3. Koefisien regresi variabel Kualitas Pelayanan $\mathbf{X}_{\mathbf{1}}$ adalah sebesar 0,128, artinya jika variabel independen lain nilainya tetap dan nilai dari Kualitas Pelayanan mengalami kenaikan 1 poin, maka nilai dari Kepuasan Pelanggan akan mengalami kenaikan sebesar 0,128 poin. Begitu pula sebaliknya, jika variabel independen lain nilainya tetap dan nilai dari Kualitas Pelayanan mengalami penurunan sebesar 0,128 poin. Dalam hal ini pengaruh dari variabel independen Kualitas Pelayanan adalah berbanding lurus dengan Kepuasan Pelanggan, artinya semakin meningkat Kualitas Pelayanan, maka nilai Kepuasan Pelanggan juga akan semakin meningkat, begitu pula sebaliknya.

4. Koefisien regresi variabel Nilai Pelanggan $\mathbf{X}_{\mathbf{2}}$ adalah sebesar 0,455 , artinya jika variabel independen lain nilainya tetap dan nilai dari Nilai Pelanggan mengalami kenaikan 1 poin, maka nilai dari Kepuasan Pelanggan akan mengalami kenaikan sebesar 0,455 poin. Begitu pula sebaliknya, jika variabel independen lain nilainya tetap dan nilai dari Nilai Pelanggan mengalami penurunan sebesar 0,455 poin. Dalam hal ini pengaruh dari variabel independen Nilai Pelanggan adalah berbanding lurus dengan Kepuasa Pelanggan, artinya semakin meningkat Nilai Pelanggan, maka nilai dari Kepuasan Pelanggan juga akan semakin meningkat, begitu pula sebaliknya.

\section{Uji Hipotesis}

Dari hasil analisis diatas dapat dilihat bahwa koefisien determinasi $\mathrm{R}$ Square sebesar adalah 0,237 artinya menunjukan bahwa pengaruh variabel Kualitas Pelayanan dan Nilai Pelanggan terhadap Kepuasan Pelanggan secara simultan adalah $23,7 \%$ dan sisanya sebesar 76,3\% dipengaruhi variabel lain.

Hasil pengujian statistik diketahui $\mathrm{F}$ hitung $=14.285>3.09$ maka artinya Sehingga dapat disimpulkan bahwa $\mathrm{H}_{0}$ ditolak $\mathrm{H}_{1}$ diterima yang artinya secara simultan Kualitas Pelayanan $\left(\mathrm{X}_{1}\right)$, dan Nilai Pelanggan $\left(\mathrm{X}_{2}\right.$ berpengaruh signifikan terhadap Kepuasan Pelanggan (Y).

\section{SIMPULAN DA SARAN}

Berdasarkan hasil penelitian dan pembahasan yang telah dilakukan ditarik kesimpulan sebagai berikut:

Secara simultan ada pengaruh yang positif antara Kualitas Pelayanan dan Nilai Pelanggan dengan Kepuasan Pelanggan. Sehingga dapat disimpulkan bahwa kedua variabel ini memiliki kontribusi terhadap Kepuasan Pelanggan di Saung Manglid Wanayasa Purwakarta.

\section{Saran}

1. Diharapkan pihak Saung Manglid meningkatkan performa pelayanan yang lebih lagi kepada para pengunjung, termasuk ketepatan waktu, kenyamanan tempat menunggu, serta pelayanan.

2. Diharapkan pihak Saung Manglid harus terus memperhatikan Kualitas pelayanan yang ditawarkan dalam upaya meningkatkan Kepuasan pelanggan dengan cara memberikan pelayanan yang maksimal pada setiap pengunjung yang datang.

\section{REFERENSI}

Anis Siyatul Nufus. (2015). Pengaruh kualitas pelayanan terhadap kepuasan konsumen di rumah makan taman jaya ujung kulon cilegon. Skripsi. Retrieved from http://repository.upi.edu

Hami, M. L. S. A., Suharyono, \& Hidayat, K. 2016. Analisis Pengaruh Nilai Pelanggan terhadap Kepuasan Pelanggan dan Dampaknya pada Loyalitas Pelanggan (Survei pada Pengguna sepeda motor Honda Vario all variant di service center Honda AHASS Sukma Motor Jalan Sigura-gura Barat Kota Malang). Jurnal Administrasi Bisnis, 39(1), 81-89.

Irawan, D., Pemasaran, J. M., Petra, U. K., \& Siwalankerto, J. 2013. Analisa Pengaruh Kualitas Produk Terhadap Loyalitas Melalui Kepuasan Sebagai Variabel Intervening Pada Pelanggan Restoran Por Kee Surabaya. Jurnal Manajemen Pemasaran, 1(2), 1-8.

Januar, P. E. 2016. Pengaruh Kualitas Pelayanan Terhadap Kepuasan Pelanggan Pada Jne Cabang Bandung. DeReMa Jurnal Manajemen, 11(2), 265289. Retrieved from file:///C:/Users/User.UserPC/Downloads/197-741-1-PB.pdf

Kotler, Philip dan Keller, K Lane. 2009. Manajemen Pemasaran Edisi 13. Jilid 1 dan 2. Jakarta : Penerbit Erlangga.

Kotler, Philip, dan Kevin Lane Keller. 2009. Manajemen Pemasaran Jilid 2, edisi 
Ketiga Belas, Terjemahan Bob Sabran, MM. Jakarta: Penerbit Erlangga.

Loindong, et.al 2014. Pengaruh Kualitas Produk, Harga dan Lokasi Terhadap Kepuasan Konsumen Pada WarungWarung Makan Lamongan di Kota Manado. Jurnal of Business and Management Sciences, 2(3), 1768-1780. https://doi.org/10.7498/aps.62.144101

Mardikawati, W., \& Farida, N. 2013. Pengaruh Nilai Pelanggan dan Kualitas Layanan terhadap Loyalitas Pelanggan pada Pelanggan Bus Efisiensi (Studi PO Efisiensi Jurusan Yogyakarta-Cilacap). Jurnal Administrasi Bisnis, 2(1), 64-75.

Munisih, S., \& Soliha, E. (2015). Pengaruh kualitas produk terhadap nilai pelanggan dan kepuasan pelanggan dan dampaknya pada loyalitas pelanggan apotek dela semarang. Jurnal Fakultas Ekonomi Dan Bisnis, Volume 2 (1).

Riyanto, Agus. 2009. Metodologi penelitian. Nuha Medika: Yogyakarta

Sembiring, I. J., Suharyono, \& Kusumawati, A. 2014. Pengaruh Kualitas Produk dan Kualitas Pelayanan Terhadap Kepuasan Pelanggan Dalam Membentuk Loyalitas Pelanggan (Studi pada Pelanggan McDonald's MT.Haryono Malang). Jurnal Administrasi Bisnis, 15(1), 1-10.

Sugiyono. 2017. Metode Penelitian Kombinasi (mixed methods). Bandung: Alfabeta.

Tjiptono, Fandy. 2001. Manajemen Jasa Edisi 2. Andi : Yogyakarta

Tjiptono, Fandy, Gregorius, Chandra. 2005. Manajemen Kualitas Jasa. Andi : Yogyakarta

Tjiptono, Fandy, Gregorius, Chandra. 2011. Service, Quality, and Satisfaction. Penerbit Andi : Yogyakarta

Imbari, S. (2018). Pengaruh Kualitas Pelayanan dan Kepuasan terhadap Loyalitas (Studi pada Nasabah Tabungan Bank Bca Cabang Purwakarta). Eqien: Jurnal Ekonomi dan Bisnis, 5(1), 40-50.

Lusiani, L., \& Nusannas, I. S. (2019). Urgensi Loyalitas Konsumen: Antara Corporate Image Atau Customer Trust. Eqien: Jurnal Ekonomi dan Bisnis, 6(1), 12-17.
Ludin, I., Saleh, H. S., \& Amruloh, D. A. G. (2018). Pengaruh Kecerdasan Intelektual, Kecerdasan Emosional, dan Kecerdasan Spiritual terhadap Kinerja Wirausaha Muslim di Kabupaten Purwakarta. Eqien: Jurnal Ekonomi dan Bisnis, 5(1), 8-18. 